\title{
PANCASILA DAN EKSISTENSI EKONOMI KERAKYATAN \\ DALAM MENGHADAPI KAPITALISME GLOBAL
}

\author{
Anita Rinawati \\ email : anita@umpwr.ac.id
}

\begin{abstract}
ABSTRAK
Globalisasi tidak dapat dihindari bagi semua bangsa, adanya globalisasi memicu masuknya kapitalisme dalam sendi sendi perekonomian Indonesia. Tujuan dari penelitian ini menganalisis eksistensi dari implementasi ekonomi kerakyatan sebagai sub sistem perekonomian yang berdasar Pancasila menghadapi gempuran kapitalisme global. Metode dalam makalah ini menggunakan metode studi literatur, dengan memaparkan teori yang berhubungan dengan judul, yang diperoleh dari jurnal, buku dokumentasi, dan internet. Ekonomi kerakyatan yang berlandaskan pada Pancasila dan UUD 45 serta Pasal 33 merupakan sistem ekonomi yang berbasis pada kekuatan ekonomi rakyat. Dimana wujud dari ekonomi rakyat sendiri berbentuk koperasi dan berbagai kegiatan ekonomi atau usaha yang dilakukan oleh rakyat dalam prakteknya berbentuk UMKM. Eksistensi dari ekonomi kerakyatan dapat terwujud dengan mengedepankan asas kekeluargaan dan keadilan berdasarkan Pancasila serta peran dari pelaku ekonomi sebagai mitra, untuk menangkal arus kapitalisme global.
\end{abstract}

Kata Kunci: Pancasila, Ekonomi Kerakyatan, Kapitalsme Global

\section{A. PENDAHULUAN}

Masuknya era globalisasi menjadikan bangsa dunia hampir tidak memiliki batas. Bahkan Mubyarto (1999) mengatakan globalisasi memang bukan musuh yang harus diperangi. Namun tetap saja kita harus ekstra waspada menghadapinya, jika kita tidak ingin di "jarah"nya. Berdasar pernyataan tersebut tentunya globalisasi memiliki dampak baik dan buruk. Saat ini dampak tersebut sudah masuk dan dirasakan apalagi jika berkaitan dengan perekonomian, masuknya globalisasi tentu akan diikuti adanya paham kapitalis yang sangat individualis dan menjunjung asas keuntungan semata.

Lukum, R. (2013) menjelaskan globalisasi yang direkayasa negara-negara besar akan memberikan dampak bagi negara-negara yang sedang berkembang, dalam bidang idiologi dihembuskan angin individualisme dan neoliberalisme yang mengutamakan kebebasan individu daripada kepentingan bersama. Dalam bidang politik, disatu sisi dilancarkan gerakan demokratisasi baik melalui cara-cara damai dengan cara menyelenggarakan reformasi politik atau dengan agresi, disamping itu juga dilancarkan usaha-usaha untuk menguasai negara-negara yang sedang berkembang secara politik dan ekonomi dalam bentuk neo-imperalisme atau penjajahan terselubung. Sementara 
bidang ekonomi yang menonjol adalah lahirnya neo-kapitalisme dengan ciri utama pergerakan modal uang secara bebas tanpa hambatan batas negara dengan memaksakan pasar bebas dan perdagangan bebas. Penanaman modal di negara-negara yang sedang berkembang mendatangkan keuntungan yang dapat langsung ditarik pulang. Tanpa disadari telah terjadi penyedotan kekayaan negara-negara yang sedang berkembang oleh negara-negara besar.

Fadilah (2019) adanya revolusi industri 4.0 menjadikan bagi tantangan ideologi Pancasila semakin kompleks dalam mengikuti perkembangan zaman seperti masuknya liberalisme, komunisme, individualisme, atheisme, kapitalisme, sementara dalam kehidupan sosial; narkoba, terorisme, dan korupis serta kebudayaan global.

Demi kelangsungan hidup negara dan bangsa Indonesia di era globlalisasi, mengharuskan kita untuk melestarikan nilai-nilai Pancasila. Hal ini menarik untuk dikaji bersama dengan berlandaskan pada dasar negara kita Pancasila yang memiliki asas kekeluargaan dan gotong royong, agar generasi penerus bangsa tetap dapat menghayati dan mengamalkannya, serta intisari nilai-nilai yang luhur itu tetap terjaga sebagai pedoman bangsa Indonesia sepanjang masa.

Pancasila sebagai pandangan hidup bangsa Indonesia harus senantiasa kita jaga dan sebagai pembimbing interaksi antar individu dan kelompok yang ada. Namun pada kenyataanya nilai-nilai Pancasila cenderung ditinggalkan dalam praktek kehidupan. Sebagai dampaknya eksistensi bangsa Indoensia yang pluralis pun kini terancam karena kebebasan yang kebablasan. Eksistensi bangsa Indonesia yang pluralistik terancam jika dasar negara dan konstitusi (Pancasila dan UUD 1945) tidak dijadikan ukuran dan acuan dalam berpikir serta berperilaku sebagai warga negara, sementara gempuran globalisasi terus menerus terjadi.

Pada sistem perekonomian negara kita menganut sistem perekonomian Pancasila. Ekonomi Pancasila merupakan sistem perekonomian yang orientasinya pada keterlibatan orang banyak dalam aktivitas ekonomi, dengan mengacu pada nilai-nilai yang digali dari falsafah Pancasila, atau ekonomi Pancasila merupakan aturan main bagi kehidupan ekonomi atau hubungan antara para pelaku ekonomi yang didasarkan pada sila-sila Pancasila. Menurut Salim, A (2019) menjelaskn bahwa ajaran utama ekonomi Pancasila bahwa dalam berekonomi semata-mata tidak hanya bermotif mengutamakan dan memaksimalkan keuntungan (profit) dan kepuasaan (utility) ekonomi, akan tetapi 
lebih pada aspek kekeluargaan, jika sekalipun rugi secara ekonomi tidak perlu dianggap gagal kalau pada waktu yang bersamaan mendapat kerabat baru (petuah Jawa).

Kenyataan yang ada Pemerintah dalam praktiknya secara fisik lebih mementingkan kaum berduit atau konglomerat, karena para konglomerat lebih dekat dengan negara dan mereka lebih banyak membayar pajak serta tidak dapat dipungkiri untuk menduduki jabatan dalam suatu lembaga peran mereka sangat besar. Pada prakteknya sistem kerakyatan tidak bisa mensejahterakan rakyat itu sendiri. Mubyarto (2002) mengatakan sistem ekonomi suatu negara haruslah sistem yang melayani rakyat banyak, sementara sistem ekonomi yang ada hanya melayani perusahaan besar. Berdasarkan hal tersebut tujuan dari penelitian ini menganalisis bagaimana eksistensi dari implementasi ekonomi kerakyatan sebagai sub sistem perekonomian yang berdasar Pancasila menghadapi gempuran kapitalisme global?

\section{B. METODE PENELITIAN}

Ruang lingkup penelitian ini mengetahui eksistensi dari ekonomi kerakyatan sebagai sub sistem perekonomian yang berdasar Pancasila menghadapi gempuran kapitalisme global.

Metode dalam makalah ini menggunakan metode studi literatur, dengan memaparkan teori yang berhubungan dengan judul, yang diperoleh dari jurnal, buku dokumentasi, dan internet.

\section{PEMBAHASAN}

\section{Kapitalisme Global}

Pasaribu, R. B. F. (2013) menjelaskan Pancasila perlu disosialisasikan agar dipahami oleh dunia sebagai landasan filosofis bangsa Indonesia dalam mempertahankan eksistensi dan mengembangkan dirinya menjadi bangsa yang sejahtera dan modern. Sebagai ideologi nasional, ia harus diperjuangkan untuk diterima kebenarannya melewati batas-batas Negara bangsa kita sendiri. Sementara lahirnya kapitalisme dijelaskan oleh Pasaribu, R. B. F. (2013) dengan di tandai pada akhir abad ke-18 dan awal abad ke-19, maka lahirlah pemikiran, teori, dan sistem ekonomi baru yang dijiwai oleh semangat liberalisme yaitu kapitalisme.

Adam Smith dan David Ricardo merupakan tokoh yang dikenal mencetuskan ide kapitalisme. Latar belakang pemikiran keduanya tidak lepas dari kehidupan ekonomi pada saat itu yang berada di bawah sistem merkantilis suatu sistem ekonomi di mana 
pemerintah berperan besar dalam membatasi kegiatan-kegiatan ekonomi guna mendorong ekspor dan membatasi impor.

Kurniawan, I. D., \& Lahir, S. (2017) menjelaskan kapitalisme merupakan salah satu organisasi ekonomi dimana hak milik privat atas alat-alat produksi dan distribusi pemanfaatannya untuk mencapai laba semaksimal mungkin dalam kondisi yang sangat kompetitif.

Ada empat penyangga berlakunya sistem ekonomi kapitalisme Ahmad Erani Yustika (2012: 220) yaitu sebagai berikut: pertama, kegiatan ekonomi dalam sisten kapitalisme digerakkan dan dikoordinasi oleh pasar bebas dengan instrumen harga sebagai penanda (sinyal). Jika harga dianggap melebihi biaya produksi dan margin laba, hal tersebut merupakan sinyal bagi pelaku ekonomi lain untuk masuk ke pasar menambah persediaan (supply) barang/jasa sehingga dapat menurunkan harga; demikian juga sebaliknya. Kedua, setiap individu memiliki kebebasan untuk mempunyai hak kepemilikan (property rights) sebagai dasar melakukan transaksi. Tanpa adanya hak kepemilikan, individu tidak akan pernah bisa mengeksekusi kegiatan ekonomi. Oleh karena itu, salah satu fungsi terpenting dari kapitalisme adalah menawarkan dan melindungi hak kepemilikan swasta. Ketiga, kegiatan ekonomi dipisahkan oleh tiga pemilik faktor produksi yakni pemodal, tenaga kerja, dan pemilik lahan. Pemilik modal memperoleh pendapatan dari laba, tenaga kerja dari upah, dan pemilik lahan dari sewa. Keempat, tidak ada halangan bagi pelaku ekonomi untuk masuk dan keluar pasar. Pelaku ekonomi yang melihat peluang profit bisa langsung pasar. Demikian pula pelaku ekonomi yang gagal (rugi) dapat langsung keluar tanpa ada regulasi yang menghambatnya.

Adanya gejala mengglobalnya sosio-cultural diantara bangsa-bangsa dimana kultur antar bangsa saling menyatu menjadi satu kultur dunia, mengakibatkan hubungan antar bangsa semakin dekat. Globalisasi biasa dikait-kaitkan dengan kemajuan teknologi informasi, spekulasi dalam pasar uang, meningkatnya arus modal lintas Negara, pemasaran massal, pemanasan global, era perusahaan multinasional hilangnya batasbatas antar Negara dan kian melemahnya kekuasaan Negara (Budiono, dalam Suparlan 2012).

Ciri-ciri adanya pengaruh globalisasi ekonomi ditandai dengan karakteristik diantaranya pertama keterbukaan ekonomi terutama adanya liberalisasi pasar, serta 
transfer teknologi secara internasional, kedua adanya keterkaitan dan ketergantungan ekonomi, keuangan, perdagangan, dan industry antar negara atau perusahaan yang ditunjukkan oleh adanya pembentukan perusahaan multinasional, ketiga kecenderungan adanya integrasi ekonomi regional.

\section{Pancasila}

Di era krisis moral ini sudah sepatutnya kita berintropeksi diri dan kembali mengenang serta menjunjung tinggi nilai etika ketuhanan dan kemanusiaan dalam bersikap, berpikir, dan bertindak sebagai mahluk ekonomi (homo economicus) agar dalam praktek ekonomi tidak mengabaikan nilai agama, sosial dan budaya. Etika-etika dalam kehidupan berbangsa dan bernegara sejatinya sudah ada dalam dasar negara kita yaitu Pancasila.

Makna sila-sila dalam Pancasila yang Kesatu: Sila Ketuhanan Yang Maha Esa, mengandung nilai spiritual, memberikan kesempatan yang seluas-luasnya kepada semua pemeluk agama dan penganut kepercayaan terhadap Tuhan Yang Maha Esa untuk berkembang di Indonesia. Nilai ini berfungsi sebagai kekuatan mental, spiritual, dan landasan etik dalam Ketahanan Nasional, maka atheisme tidak berhak hidup di bumi Indonesia dalam kerukunan dan kedamaian hidup beragama.

Kedua Sila Kemanusiaan Yang Adil dan Beradab, tersimpul nilai satu derajat, sama kewajiban dan hak, saling mencintai, hormat menghormati, keberanian membela kebenaran dan keadilan, toleransi dan nilai gotong royong. Ketiga Sila Persatuan Indonesia. mengandung nilai-nilai kebangsaan, cinta tanah air dan rela berkorban demi kepentingan bangsa dan Negara. Keempat Sila kerakyatan Yang Dipimpin oleh Hikmat Kebijaksanaan dalam Permusyawaratan / Perwakilan, mengandung nilai kedaulatan berada di tangan rakyat (demokrasi) yang dijelmakan oleh persatuan nasional yang riil dan wajar. Meskipun nilai ini mengutamakan kepentingan Negara / bangsa akan tetapi tetap menghargai kepentingan pribadi dan golongan, musyawarah untuk mufakat dan menjunjung tinggi harkat dan martabat serta nilai kebenaran dan keadilan. Kelima Sila Keadilan Sosial Bagi Seluruh Rakyat Indonesia, mengandung nilai sikap adil, menghormati hak orang dan sikap gotong royong, yang menjamin kemakmuran masyarakat secara menyeluruh dan adil.

Lebih detail Mubyarto (1999: 16) menjelaskan bahwa sila pertama dan kedua sebagai landasan moralnya, ada etika yang harus dipegang dan dijalankan dalam 
perekonomian, sila ketiga dan keempat sebagai cara atau metode kerjanya, yang selalu menjunjung asas kekeluargaan, gotong-royong dan tolong menolong antarapelaku ekonomi, sedangkan sila kelima sebagai tujuan akhir dari pengamalannya, dimana tujuan akhir pembangunan sosial adalah dapat mewujudkan keadilan sosial bagi seluruh rakyat Indonesia.

Tujuan berbangsa dan bernegara merujuk pada pembukaan UUD 1945 untuk: (a) Melindungi segenap bangsa Indonesia dan seluruh tumpah darah Indonesia; (b) Memajukan kesejahteraan umum; (c) Mencerdaskan kehidupan bangsa, dan (d) Ikut melaksanakan ketertiban dunia berdasarkan kemerdekaan, perdamaian abadi dan keadilan sosial. Selanjutnya untuk memperjelas maka dalam Pasal 33 UUD 1945 juga memuat beberapa prinsip ekonomi, yaitu: (a) Perekonomian disusun sebagai usaha bersama atas asas kekeluargaan; (b) Cabang-cabang produksi yang menguasai hajat hidup orang banyak dikuasai oleh Negara; (c) Bumi, air dan kekayaan alam yang terkandung didalamnya dikuasai oleh negara dan dipergunakan sebesar-besanya untuk kesejahteraan rakyat; dan (d) Perekonomian nasional diselenggarakan berdasar atas demokrasi ekonomi dengan prinsip kebersamaan, efisiensi berkeadilan, berkelanjutan, berwawasan lingkungan, kemandirian, serta dengan menjaga keseimbangan kemajuan dan kesatuan ekonomi nasional.

Hosein, Z. A. (2016) menjelaskan bahwa dalam perspektif prinsip ekonomi kerakyatan sebagaimana yang diamanatkan oleh para perumus Pasal 33 UUD 1945, maka beberapa kebijakan atau politik hukum di bidang ekonomi pada masa orde baru dan orde reformasi dapat dinilai telah menjauh dari prinsip yang dianut oleh Pasal 33 UUD 1945. Apabila segala kebijakan di bidang ekonomi tidak sejalan dengan UUD 1945 sebagai hukum tertinggi, maka kebijakan ekonomi yang diambil dan ditetapkan dianggap bertentangan dengan UUD 1945.

Dalam sisi hukum maka jelas bahwa pereknomian Indonesia berdasarkan pada Pancasila, sementara pada pelaksanaannya sudah dijelaskan di dalam Pasal 33 UUD 1945 dimana prinsip ekonomi kerakyatan lebih selaras dengan kehidupan bangsa Indonesia.

\section{Ekonomi Kerakyatan}

Istilah dan konsep ekonomi kerakyatan menurut Pohan, dkk (2019) merupakan hasil buah pikir yang diperkenalkan oleh Muhammad Hatta. Ide itu ia tuangkan ke 
dalam kertas kerjanya yang berjudul "Ekonomi Rakyat dalam Bahaya" pada tahun 1934. Tulisan tersebut telah menjadi dasar konsep ekonomi kerakyatan sebagai tandingan atas sistem ekonomi Belanda yang didukung dan dibantu oleh kaum aristrokat dalam sistem feodalisme. Sistem ekonomi kerakyatan berbasis pada kekuatan rakyat, sedangkan ekonomi rakyat adalah kegiatan ekonomi yang dilakukan dengan cara swadaya untuk mengelola sumber daya yang ada di sekitarnya.

Ekonomi Pancasila dirumuskan berdasar asas kebersamaan dan kekeluargaan, berbasis pada ideologi Pancasila dan UUD 45, di mana dalam Pancasila tersebut manusia mencari keseimbangan antara hidup sebagai pribadi, dan hidup sebagai anggota masyarakat. Jika kita mencermati lebih dalam lagi tentang Pasal 33 Ayat (1) UUD 1945 terlihat bahwa sistem perekonomian Indonesia menganut asas kekeluargaan. Asas kekeluargaan dipandang sebagai asas bersama yang bermakna dalam konteks sekarang yaitu persaudaraan, humanisme, dan kemanusiaan. Jadi ekonomi tidak dipandang sebagai wujud sistem persaingan liberal akan tetapi ada nuansa moral dan kebersamaannya, sebagai refleksi dari tanggung jawab sosial.

Sejak terjadinya reformasi di Indonesia pada tahun 1998, pemerintah berupaya untuk melaksanakan kembali sistem ekonomi kerakyatan. Sebagai wujud dari ditetapkannya sistem ekonomi tersebut maka ditetapkan dengan TAP MPR Nomor IV/MPR/1999, tentang Garis-Garis Besar Haluan Negara yang menyatakan bahwa sistem perekonomian Indonesia adalah Sistem Ekonomi Kerakyatan. (Bhudianto, W, 2012). Ciri dari sistem ekonomi kerakyatan berazaskan kekeluargaan, berkedaulatan rakyat, bermoral Pancasila, dan menunjukkan pemihakan sungguh-sungguh pada ekonomi rakyat. Syarat mutlak berjalannya sistem ekonomi nasional yang berkeadilan sosial adalah berdaulat di bidang politik, mandiri di bidang ekonomi, dan berkepribadian di bidang budaya. (Mubyarto, 2002 )

Sementara Arini Nurmala Sari, (2011) juga menjelaskan tentang Sistem Ekonomi Kerakyatan mempunyai ciri-ciri sebagai berikut: (1) Bertumpu pada mekanisme pasar yang berkeadilan dengan prinsip persaingan sehat; (2) Memperhatikan pertumbuhan ekonomi, nilai keadilan, kepentingan sosial ,dan kualitas hidup; (3) Mampu mewujudkan pembangunan berwawasan lingkungan dan berkelanjutan; (4) Menjamin kesempatan yang sama dalam berusaha dan bekerja; dan (5) Adanya perlindungan hak-hak konsumen dan perlakuan yang adil bagi seluruh rakyat. Pada 
Sistem Ekonomi Kerakyatan juga dijelaskan bahwa pemerintah harus dapat menciptakan iklim yang sehat bagi pertumbuhan dan perkembangan dunia usaha sementara masyarakat memegang aktif dalam kegiatan ekonomi.

Pada kegiatan perekonomian yang meliputi aktivitas produksi, distribusi, dan konsumsi, ketiganya memiliki motif memaksimalkan keuntungan (profit) dan kepuasaan (utility). Oleh karena itu, usaha memaksimalkan keuntungan maupun kepuasaan harus merujuk pada ekonomi kerakyatan yang berpedoman pada sila-sila Pancasila dengan memperhatikan etika ketuhanan dan kemanusiaan.

Dalam kehidupan berekonomi yang merujuk pada Pancasila sila Kesatu menurut Salim, A. (2019) dapat diimplementasikan sebagai berikut :

a. Memperhatikan ajaran agama dengan kata lain, apakah barang dan jasa yang diproduksi, didistribusi dan dikonsumsi bertentangan atau tidak dengan ajaran Tuhan. Contohnya, jika memproduksi, mendisribusi dan mengkonsumsi barang yang tergolong dilarang agama misalnya narkotika dan obat-obatan terlarang (narkoba), minuma keras (miras), atau jenis barang dan jasa lain yang memiliki nilai keburukannya lebih tinggi daripada manfaatnya karena dalam konteks nilai kemanusiaan dapat merugikan diri sendiri dan orang lain. Sementara di sektor moneter, di masyarakat juga sering sekali terjadi berupa kegiatan rentenir, ini juga secara agama dilarang sebab membungakan uang, bahkan Plato juga dalam pendapatnya bahwa uang itu bersifat mandul jadi tidak boleh diperanakkan, dan hal ini bertentangan dengan ajaran agama.

b. Adanya keyakinan kegiatan kita selalu diawasi oleh Tuhan. Dalam keadaan tertutup (sembunyi) dari pengawasan orang lain, sebagai manusia yang berTuhan kita wajib meyakini dengan sepenuh hati bahwa Tuhan itu Maha Tahu, sehingga merasa selalu diawasi oleh Tuhan kapan dan di manapu berada. Adanya praktek pengadaan proyek yang tidak fair tentu juga merupakan salah satu bentuk kecurangan. Setiap pelaku ekonomi seharusnya sadar bahwa Tuhan selalu mengawasi setiap aktivitas kita.

c. Keyakinan adanya imbalan dari Tuhan. Segala bentuk aktivitas ekonomi yang bertentangan dan/atau sesuai dengan ajaran Tuhan pasti akan mendapat imbalan atau ganjaran yang setimpal dari Tuhan, baik di dunia maupun di akhirat. 
Berdasarkan hasil internalisasi dasar ekonomi Pancasila terutama sila kesatu di atas, dapat disimpulkan bahwa terdapat rangkaian sistem (hubungan) antara etika ketuhanan dengan kemanusiaan, dimana hal ini tidak ditemukan dalam paham kapitalis yang lebih mengutamakan unsur profit motif.

\section{Eksistensi Ekonomi Kerakyatan Dalam Menghadapi Kapitalisme}

Asas kekeluargaan belum cukup untuk menjamin kemajuan ekonomi tanpa adanya semangat nasionalisme apalagi ditengah gempuran arus globalisasi dan masuknya kapitalisme di sendi sendi usaha. Ekonomi kerakyatan pada dasarnya merupakan unsur dari sistem ekonomi pancasila itu sendiri, dimana didalamya terkandung unsur-unsur moral Pancasila seperti gotong royong, kekeluargaan saling menolong. Asas kekeluargaan, hakikatnya merupakan jatidiri bangsa Indoensia..

Asas keadilan sosial di bidang ekonomi berkaitan dengan keadilan antara para pelaku ekonomi yang tercermin pada kesadaran masing-masing pelaku ekonomi akan pentingya rasa tanggung jawab sosial dan agama terhadap pelaku ekonomi lainnya. Wujudnya dengan menjalin kemitraan antar lembaga dan pelaku ekonomi yang berlandaskan asas kekeluargaan. Oleh karena itu, menumbuhkan secara terus menerus semangat menjauhi keserakahan dan eksploitasi adalah hal utama yang harus disadari dan diwujudkan dalam bentuk perbuatan nyata bagi seluruh pelaku ekonomi di Indonesia

Lebih jelasnya tentang penerapan asas kekeluargaan dalam berekonomi, dapat digambarkan model penerapan asas kekeluargaan untuk memperkuat ekonomi kerakyatan :

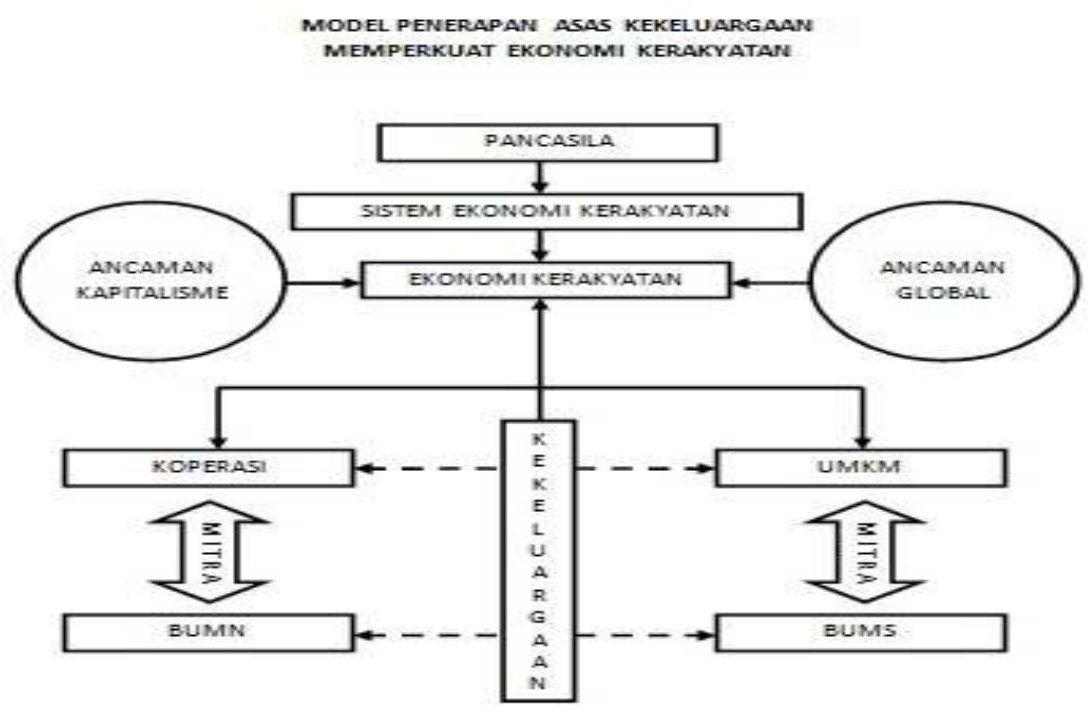


Pancasila sebagai dasar terwujudnya sistem ekonomi Pancasila yang dalam penerapannya menjelma menjadi perekonomian yang berbasis pada kesejahteraan rakyat atau ekonomi kerakyatan. Implementasi Ekonomi Kerakyatan berbentuk badan usaha Koperasi dan UMKM.

Pohan, dkk(2019) menjelaskan sejarah awal adanya koperasi merupakan bukti keprihatinan Muhammad Hatta akan kondisi ekonomi masyarakat di Indonesia. Koperasi ditawarkan guna menunjukan semangat kolektivitas dan gotong royong serta tolong menolong. Kedua spirit ini menjadi dasar dari budaya bangsa Indonesia. Koperasi kemudian diakui dan diterima sebagai salah satu bentuk badan usaha dalam sistem ekonomi kerakyatan.

Koperasi dan UMKM tidak akan dapat eksis di percaturan dunia usaha jika tidak menjalin kemitraan dengan BUMN dan BUMS serta didukung oleh pemerintah melalui perlindungan dengan Undang-Undang. Pemerintah perlu membuat pengaturan yang lebih khusus untuk usaha kecil, UKM dan UMKM, misalkan dapat dibuatkan aturan yang sedikit protektif, artinya negara, melalui lembaga di bawahnya, seperti Badan Koordinasi Penanaman Modal, Dinas Penanaman Modal dan Perindustrian di tingkat provinsi/kabupaten bisa membuat aturan yang lebih spesifik. Misalkan pada tingkat permodalannya dan usaha hanya boleh dikelola oleh UKM/UMKM

Lebih lanjut Salim, A. (2019) menjelaskan bahwa pengembangan gerakan kekeluargaan melalui kemitraan antara pelaku ekonomi dapat dilakukan dalam berbagai pola, seperti peningkatan kualitas dan kapasitas usaha, perencanaan, dan promosi produk serta permodalan bagi jalur ekonomi kerakyatan yang intinya diarahkan untuk pengembangan koperasi dan UMKM sebagai pelaku ekonomi jalur ekonomi kerakyatan. Melalui gerakan kekeluargaan diharapkan dapat memberdayakan jalur ekonomi kerakyatan yang berorientasi menciptakan pemerataan dan bagi pelaku ekonomi koorporasi dapat mempercepat dan mempertinggi pertunbuhan perekonomian nasional. Jadi prinsipnya adalah saling memerlukan, memperkuat dan menguntungkan.

Implementasi ekonomi kerakyatan akan lebih efektif jika sudah diajarkan dari sejak dini melalui sekolah, hal ini akan memberikan karakter semangat nasionalisme yang akan mewujudkan rasa kekeluargaan yang tidak semata-mata mengejar profit serta memiliki etika keadilan. Mubyarto (2004) homo-economicus ala kapitalis barat yang bermotifkan hanya memaksimalkan keuntungan (profit) dan kepuasaan (utility) atas 
barang dan jasa yang terbatas, sayangnya pertama-tama telah diajarkan di sekolah. Pendidikan ekonomi di Indonesia yang didambakan untuk menjadikan anak bangsa sebagai sumber daya manusia pelaku ekonomi yang bangga untuk mengamalkan nilainilai ekonomi berlandaskan pada ideologi Pancasila dan UUD 1945, namun dalam kenyataanya pendidikan ekonomi kita malah menjauhkan anak bangsa Indonesia sendiri dari karakter nilai-nilai dasar ekonomi Pancasila. Pada akhirnya semakin menjauhkan implementasi ekonomi kerakyatan dalam praktek ekonomi.

\section{KESIMPULAN}

Ekonomi kerakyatan yang berlandaskan pada Pancasila dan UUD 45 serta Pasal 33 merupakan sistem ekonomi yang berbasis pada kekuatan ekonomi rakyat. Dimana wujud dari ekonomi rakyat sendiri berbentuk koperasi dan berbagai kegiatan ekonomi atau usaha yang dilakukan oleh rakyat kebanyakan yang dengan secara swadaya mengelola sumberdaya ekonomi apa saja yang dapat diusahakan dan dikuasainya, yang selanjutnya disebut sebagai Usaha Kecil dan Menegah (UKM) terutama meliputi sektor pertanian, peternakan, kerajinan, makanan, dsb., yang ditujukan terutama untuk memenuhi kebutuhan dasarnya dan keluarganya tanpa harus mengorbankan kepentingan masyarakat lainnya. Eksistensi dari ekonomi kerakyatan dapat terwujud dengan mengedepankan asas kekeluargaan dan peran dari pelaku ekonomi sebagai mitra, untuk menangkal arus kapitalisme global.

\section{E. DAFTAR ISI}

Abdi, M. N. (2020). Krisis Ekonomi Global Dari Dampak Penyebaran Virus Corona (Covid-19). AkMen Jurnal Ilmiah, 17(1), 90-98.

Ahmad Erani Yustika. 2014. Ekonomi Kelembagaan: Paradigma, Teori, dan Kebijakan. Jakarta: Erlangga

Asmaroini, A. P. (2017). Menjaga Eksistensi Pancasila Dan Penerapanya Bagi Masyarakat di Era Globalisasi. JPK: Jurnal Pancasila dan Kewarganegaraan, $1(2), 50-64$.

Bhudianto, W. (2012). Sistem ekonomi kerakyatan dalam globalisasi perekonomian. Transformasi, XIV No, 22.

Fadilah, N. (2019). Tantangan dan Penguatan Ideologi Pancasila Dalam Menghadapi Era Revolusi Industri 4.0. Journal Of Digital Education, Communication, And Arts (Deca), 2(02), 66-78. 
Hosein, Z. A. (2016). Peran Negara dalam Pengembangan Sistem Ekonomi Kerakyatan Menurut UUD 1945. Jurnal Hukum Ius Quia Iustum, 23(3), 503-528.

Kurniawan, I. D., \& Lahir, S. (2017). Sistem Kapitalisme Negara Sebagai Alternatif Sistem Ekonomi Kerakyatan Berdasarkan Pancasila. Jurnal Ilmiah Edunomika, $1(02)$.

Lukum, R. (2013). Peran Ideologi Pancasila Dalam Kebijakan Politik Luar Negeri Indonesia Sebagai Solusi Menghadapi Pengaruh Globalisasi.

Mubyarto, (1999), Reformasi Sistem Ekonomi (Dari Kapitalisme menuju Ekonomi Kerakyatan). Yogyakarta :Aditya Media

Mubyarto, M. (2001). Siklus tujuh tahunan ekonomi Indonesia (1931-1966-2001-2036). Journal of Indonesian Economy and Business, 16(3).

Mubyarto (2002), Ekonomi Kerakyatan dalam Era Globalisasi, Jurnal Ekonomi Kerakyatan, Yogyakarta

Mubyarto \& Santosa, A. (2004). Pendidikan Ekonomi Alternatif di Sekolah-sekolah Lanjutan.

Pasaribu, R. B. F. (2013) .Pancasila Sebagai Ideologi Nasional.

Pohan, I. A., Krisdayanti, A. E., \& Simanjuntak, D. B. (2019). Rekonstruksi Pemikiran Ekonomi Kerakyatan Mohammad Hatta. Jurnal Ilmu Politik dan Pemerintahan, $4(1), 11$.

Salim, A. (2019). Ekonomi Pancasila Dan Implikasinya Dalam Pembelajaran Ekonomi. Penkomi: Kajian Pendidikan Dan Ekonomi, 2(1), 16-30.

Saputra, I., \& Saoqillah, A. (2017). Koperasi Sebagai Soko Guru Penggerak Ekonomi Pancasila. Jurnal Riset Manajemen dan Bisnis (JRMB) Fakultas Ekonomi UNIAT, 2(2), 139-146.

Venusita, L. (2014). Reposisi Fungsi Lembaga Keuangan Bank dan Non Bank dalam Upaya Pemberdayaan Ekonomi Kerakyatan, Penerapan Good Governance dan Pengembangan Otonomi Daerah. Jurnal Akuntansi Aktual, 2(3), 186-194.

Wicaksono, E. K. A. L. H. (2016). Peran Paguyuban Pedagang Lokal Sekaran dalam Menguatkan Ekonomi Kerakyatan di Kelurahan Sekaran Kota Semarang. In Forum Ilmu Sosial (Vol. 43, No. 1, pp. 13-25). 